\title{
A Culture-Independent and Culture-Dependent Study of the Bacterial Community from the Bedrock Soil Interface
}

\author{
Karen Olsson-Francis ${ }^{1}$, Carl P. Boardman², Victoria K. Pearson ${ }^{3}$, Paul F. Schofield ${ }^{4}$, \\ Anna Oliver ${ }^{5}$, Stephen Summers ${ }^{2}$ \\ ${ }^{1}$ Department of Environment, Earth and Ecosystems, The Open University, Milton Keynes, UK \\ ${ }^{2}$ Department of Engineering and Innovation, The Open University, Milton Keynes, UK \\ ${ }^{3}$ Department of Physical Sciences, The Open University, Milton Keynes, UK \\ ${ }^{4}$ Department of Earth Sciences, Natural History Museum, London, UK \\ ${ }^{5}$ NERC Centre for Ecology and Hydrology, Wallingford, UK \\ Email: "k.olsson-francis@open.ac.uk
}

Received 22 September 2015; accepted 12 December 2015; published 15 December 2015

Copyright (C) 2015 by authors and Scientific Research Publishing Inc.

This work is licensed under the Creative Commons Attribution International License (CC BY). http://creativecommons.org/licenses/by/4.0/

(c) (i) Open Access

\section{Abstract}

In nutrient limited soils, minerals constitute a major reservoir of bio-essential elements. Consequently, the release of nutritive elements during weathering is crucial. Bacteria have been shown to enhance weathering rates; however, there has been limited work that has focused on the bacterial weathering of bedrock or parent rock, which are the major sources of minerals, in nutrient limiting soils. In this study, both a culture-independent and culture-dependent approach was used to study the bacterial community at the interface between basaltic bedrock and nutrient limiting soil in Cadiar Idris region of Snowdonia National Park, United Kingdom. High throughput sequencing method, Ion Torrent, was used to characterise the bacterial community, which generated over 250,000 sequences. Taxonomical assignment demonstrated that approximately $50 \%(125,000$ sequences) of the community consisted of the orders Actinomycetales, Burkholderiales, Clostridales, Bacillales, Rhizobiales and Acidobacterium, with unclassified sequences representing $44 \% \pm$ $1.46 \%(110,000 \pm 3650)$. Bacteria belonging to the genera Serratia, Pseudomonas, Bacillus, Paenibacillus, Chromobacterium, Janthinobacterium, Burkholderia and Arthrobacter, were isolated from the sample site. All of the isolates were able to grow in a minimal growth medium, which contained glucose, ammonium chloride with basalt as the sole source of bio-essential elements. Seventy percent of the isolates significantly enhanced basalt dissolution $(p<0.05)$. The rate of dissolution correlated to the production of oxalic acid and acidification of the growth medium. The findings of this work suggest that at the interface between bedrock and soil heterotrophic members of the bacterial community can enhance weathering, an essential part of biogeochemical cy-

\footnotetext{
${ }^{*}$ Corresponding author.
}

How to cite this paper: Olsson-Francis, K., Boardman, C.P., Pearson, V.K., Schofield, P.F., Oliver, A. and Summers, S. (2015) A Culture-Independent and Culture-Dependent Study of the Bacterial Community from the Bedrock Soil Interface. Advances in Microbiology, 5, 842-857. http://dx.doi.org/10.4236/aim.2015.513089 


\section{cling in nutrient limiting soil.}

\section{Keywords}

\section{Mineral Weathering, Soil Microbial Communities, Basalt Dissolution}

\section{Introduction}

Rock weathering plays an important role in regulating the geochemistry of soil, rivers and seawater [1] [2]. It represents a source of nutrients for terrestrial ecosystems, plays a central role in soil and sediment formation and is an important process in the long-term carbon cycle [2]-[7]. In nutrient limiting soils, such as acidic soils, minerals constitute a major reservoir of bio-essential cations, for example, calcium, potassium and magnesium [8]. The majority of minerals originate from bedrock, which are the underlying geological materials that weather to form soil. Of particular interest is basaltic material, which has comparatively low silica content compared to other silicate material and subsequently a high rate of weathering [4] [5].

The physical, chemical and biological processes involved in weathering have been recognised [9]-[12]. The extent by which biotic processes enhance weathering has been argued to be between two and a hundred-fold [13] [14]. Plants, fungi and bacteria have been shown to increase the rate of mineral weathering (for reviews on the role of plants and fungi see [15] and [16], respectively). Bacteria are able to accelerate the rate of elemental release from minerals either directly through the acquisition of limiting nutrients, or indirectly through the production of metabolic by-products that lower the $\mathrm{pH}$ or change the saturation state of the mineral [8]-[18]. Bacteria have been shown to significantly improve plant nutrition and promote plant growth due to their effect on mineral weathering [8] [17] [18].

The presence of minerals in soils and aquifers has been shown to influence the diversity of microbial communities [19]-[24]. These studies have predominantly focused on single minerals using in-situ mesocosm experiments, with a small number studying volcanic or deglaciated environments. The communities have often been studied using culture-independent methods and long-term experiments have demonstrated a correlation between mineral dissolution and community diversity, in nutrient poor acidic soils [18] [25]. However, it is difficult to determine if this is due to weathering (abiotic and biotic) increasing the bioavailability of inorganic nutrients in the surrounding soil or due to their active role in weathering [18] [25].

To address the role of bacteria in mineral weathering a parallel culture-independent and culture-dependent approach is required. Laboratory based work has focused on bio-weathering of individual minerals [18]. There has been only a small number of studies at the whole rock scale, where the rate of dissolution and reaction pathways would be different [26]-[30]. In these studies, the bacteria were either purchased commercially or isolated from exposed rocks, rather than from the interface between rock and soil. In light of the important role that weathering has in nutrient limited soils, determining the potential role of the bacterial community is pertinent.

The focus of this paper is to investigate the potential role that bacteria perform in rock weathering in nutrient limiting soils. The study centres on the Cadiar Idris region of Snowdonia National Park, United Kingdom, which is characterised by exposed rock, areas of rock debris and shallow soil, which is poor in nutrients [31]. The local geology includes basaltic material, which is a major source of inorganic bio-essential elements, such as calcium and magnesium. Insight into the bacterial diversity was obtained using a high throughput sequencing approach. In parallel, dissolution experiments in batch culture were carried out to determine the weathering ability of members of the bacterial community. To our knowledge, this paper is the first to use both high throughput sequencing and culture-dependent experiments concurrently to study bio-weathering of bedrock in a nutrient poor soil.

\section{Material and Methods}

\subsection{Sample Collection}

The sample sites for this study were within the Cadair Idris region of Snowdonia National park, United Kingdom. Soil samples $(n=3)$ were collected from four sites (Site $1,52^{\circ} 42.40 \mathrm{~N}, 3^{\circ} 54.38 \mathrm{~W}$; Site $2,52^{\circ} 42.38 \mathrm{~N}$, 
$3^{\circ} 54.39 \mathrm{~W}$; Site $3,52^{\circ} 41.10 \mathrm{~N}, 3^{\circ} 54.12 \mathrm{~W}$; Site $4,52^{\circ} 39.45 \mathrm{~N}, 3^{\circ} 46.43 \mathrm{~W}$ ), which were located at the base of basalt outcrops that had similar vegetation (arctic-alpine grassland) and a similar soil type, (acid peat soil). X-ray diffraction (XRD) and X-ray fluorescence (XRF) analysis suggested that the composition of the bedrock was basaltic [27] [32]. Plagioclase (albitic), augite, clinochlore/chlorite and zeolite were the major phases identified from XRD analysis and the major elements, which were identified with XRF, are shown in Table 1.

Samples were collected from approximately $15 \mathrm{~cm}$ beneath the surface at the interface between the soil and rock. From each of the sites, triplicate soil samples were collected from below any visible root systems. Samples were collected aseptically in May 2013 using corers, which were $5 \mathrm{~cm}$ long and $4.8 \mathrm{~cm}$ in diameter, and placed in sterile bags (Whirlpak, Fischer Scientific). Between sampling the core tip and cap were cleaned with 95\% ethanol and then rinsed with autoclaved dd $\mathrm{H}_{2} \mathrm{O}$. The samples were kept at ambient temperature during field work and transported at $4^{\circ} \mathrm{C}$ (for approximately four hours). On return to the laboratory, the top surface of the core $(1 \mathrm{~cm}$ in depth), which had been in contact with the rock, was aseptically removed from each of the cores, using a sterilised scalpel, and stored at $-20^{\circ} \mathrm{C}$, for DNA extraction, or at $4^{\circ} \mathrm{C}$ for culture and geochemical analyses. The $\mathrm{pH}$ of the soil was measured using an Orion 3-Star Thermo Scientific bench top meter, as previously described [33].

\subsection{Community Analysis of Sample Site}

For the community analysis, DNA was extracted from each of the four sample sites $(n=3)$. DNA was extracted from $1 \mathrm{~g}$ of soil using the bead-beating phenol extraction protocol previously described by Griffiths et al. [34]. The DNA was PCR amplified using a set of primers specific to the V3 - V6 hypervariable region of the bacterial 16S rRNA gene, as listed in Table S1 [35]. For each set of primers, the PCR mixture contained (per $50 \mu \mathrm{L}$ ): 4 $\mu \mathrm{L}$ of template DNA (c. $50 \mathrm{ng}$ ); $44 \mu$ l Platinum ${ }^{\circledR}$ PCR high fidelity supermix (Life technologies, Paisley, UK); 1 $\mu \mathrm{L}$ tagged forward primer and $1 \mu \mathrm{L}$ reverse primer. The PCR products were extracted from a $1.25 \%$ gel using an Illustra $^{\mathrm{TM}}$ GFX $^{\mathrm{TM}}$ gel extraction kit (GE Healthcare, UK) according to the manufactures instructions prior to quantification using an Agilent 2200 TapeStation system. An eqimolar mix of PCR products was prepared and diluted to $20 \mathrm{pM}$ in sterile $\mathrm{ddH}_{2} \mathrm{O}$, creating a tagged amplicon library. The PCR product was sequenced from the 5' end and encompassed only the V3 region. Sequencing was carried out using an Ion Torrent Personal Genome Machine (Life Technologies, Paisley UK) with a 316 chip.

\subsection{Bioinformatic Analyses}

The raw sequence data were processed and analysed using a variation to MOTHUR's Costello pipeline [36]. Reads were removed from further analysis if one of the following criteria were met: i) the read length was

Table 1. Major oxide composition (weight (\%)) of the basalt from Cadair Idris, Snowdonia National Park, United Kingdom.

\begin{tabular}{|c|c|c|c|c|}
\hline \multirow[t]{2}{*}{ Oxides } & \multicolumn{4}{|c|}{ Weight (\%) } \\
\hline & Site 1 & Site 2 & Site 3 & Site 4 \\
\hline $\mathrm{SiO}_{2}$ & 48.66 & 49.23 & 49.12 & 49.02 \\
\hline $\mathrm{TiO}_{2}$ & 2.11 & 2.09 & 2.12 & 2.1 \\
\hline $\mathbf{A l}_{2} \mathbf{O}_{3}$ & 15.87 & 15.31 & 15.42 & 15.2 \\
\hline $\mathrm{Fe}_{2} \mathrm{O}_{3}$ & 12.03 & 13.07 & 12.98 & 13.05 \\
\hline MnO & 0.21 & 0.23 & 0.23 & 0.25 \\
\hline MgO & 5.56 & 5.05 & 5.32 & 5.24 \\
\hline $\mathrm{CaO}$ & 7.21 & 6.31 & 6.15 & 6.2 \\
\hline $\mathrm{Na}_{2} \mathrm{O}$ & 2.69 & 3.79 & 2.65 & 2.89 \\
\hline $\mathbf{K}_{2} \mathbf{O}$ & 0.41 & 0.51 & 0.45 & 0.5 \\
\hline $\mathbf{P}_{2} \mathbf{O}_{5}$ & 0.31 & 0.35 & 0.36 & 0.36 \\
\hline LOI & 5.02 & 4.15 & 5.25 & 4.32 \\
\hline Total & 100.08 & 100.09 & 100.05 & 99.13 \\
\hline
\end{tabular}


shorter than $150 \mathrm{bp}$; ii) number of ambiguous bases greater than zero. The sequences were grouped based on the unique barcode attached to each sample site. The sequences were analysed using the chimeric checking algorithm UCHIME and those identified as chimeric were excluded from further analysis [37]. Sequences were aligned against the Silva sequence database and taxonomically classified using the Naïve Bayesian rRNA Classifier tool part of the Ribosomal Database Project (RDP) classifier within MOTHUR [38]-[40]. The sequences for each sample site $(n=3)$ were pooled. Rarefaction curves were generated using MG-RAST and all sequences obtained in this study were submitted to MG-RAST, under identification numbers 4548120.3 to 4548123.3 [41].

\subsection{Isolation and Identification of Bacteria}

Fresh soil samples were used to isolate bacteria from the sample sites. The soil was scattered onto agar plates, which contained $0.5 \mathrm{~g}$ of powdered basalt (fraction size $<100 \mu \mathrm{m}$ ), 65 of $\mathrm{NH}_{4} \mathrm{Cl} \mathrm{mg} \cdot \mathrm{L}^{-1}$ and $15 \mathrm{~g} \cdot \mathrm{L}^{-1}$ of Bacto Agar. The plates were incubated at room temperature, in the dark, for four weeks and then sub-cultured to obtain pure cultures. The isolates were maintained on a modified minimal medium plate, which contained the following (mg. $\mathrm{L}^{-1}$ ): 10 of $\mathrm{FeCl}_{3}, 150$ of $\mathrm{MgSO}_{4} \cdot 6 \mathrm{H}_{2} \mathrm{O}, 20$ of $\mathrm{CaCl}_{2} ; 20$ of $\mathrm{KCl}, 65$ of $\mathrm{NH}_{4} \mathrm{Cl}, 100$ of $\mathrm{NaNO}_{3}, 70$ of $\mathrm{K}_{2} \mathrm{HPO}_{4}, 60$ of $\mathrm{KH}_{2} \mathrm{PO}_{4}, 20$ of glucose and $15 \mathrm{~g} \cdot \mathrm{L}^{-1}$ of Bacto Agar.

To identify the isolates, the near-full length 16S rRNA gene was sequenced. Total nucleic acids were extracted from the isolates using the Phe:Chl:Iaa bead beating protocol described by Griffiths et al. [34]. The 16S rRNA gene was amplified using two set of primers: 27f-Com2 and Com1-1541r, which are listed in Table S2 [42]-[44]. For each of the primer sets, the PCR mixture contained (per $50 \mu \mathrm{L}$ ): $1 \mu \mathrm{L}$ of template DNA (c. $50 \mathrm{ng}$ ); $0.1 \mathrm{mM}$ dNTP mixture (New England Biolabs); $250 \mathrm{pM}$ of each primer; $1.5 \mathrm{U}$ of Taq DNA polymerase; $5 \mu \mathrm{g}$ Bovine Serum Albumin (New England Biolabs); 1× PCR Buffer (10 mM Tris-HCl (pH 8.3), $50 \mathrm{mMKCl}$ ) and $1.5 \mathrm{mM} \mathrm{MgCl} 2$ (New England Biolabs). Amplification consisted of: $94^{\circ} \mathrm{C}$ for $10 \mathrm{~min}$; followed by 35 cycles of $40 \mathrm{sec}$ at $94^{\circ} \mathrm{C}, 40 \mathrm{sec}$ at $58^{\circ} \mathrm{C}$ and a 1 min extension at $72^{\circ} \mathrm{C}$; with a final extension of $5 \mathrm{~min}$ at $72^{\circ} \mathrm{C}$. The PCR products were gel extracted from a $1 \%$ Agarose gel using an Illustra ${ }^{\mathrm{TM}} \mathrm{GFX}^{\mathrm{TM}}$ gel extraction kit (GE Healthcare, UK) according to the manufacturer's instructions. DNA sequencing of the PCR products was carried out directly by Beckman Coulter (Essex, UK). BioEdit software (v. 7.1.3.0) was used to align the sequences and the resulting contigs were approximately $1500 \mathrm{bp}$ in length. The nearest sequences were identified in the GenBank database using the BLASTN program [45]. All contiguous sequences were deposited into Genbank, as shown in Table 2.

\subsection{Basalt Dissolution Experiment}

The dissolution experiments were carried out in batch culture. The growth medium contained the following $\left(\mathrm{L}^{-1}\right)$ : $2 \mathrm{~g}$ of glucose, $0.06 \mathrm{~g}$ of $\mathrm{NH}_{4} \mathrm{Cl}$ and $200 \mathrm{~g}$ of basalt. Twenty grams of basalt, which had been prepared by

Table 2. Identification of the bacteria isolated from the interface between the basaltic bedrock and nutrient poor soil.

\begin{tabular}{|c|c|c|c|c|c|}
\hline Isolate & Genebank no & $\begin{array}{c}\text { Closest GenBank } \\
\text { relative }\end{array}$ & $\begin{array}{c}\text { Sequence identify } \\
(\%)\end{array}$ & Order & $\begin{array}{c}\text { Siderophore } \\
\left(\mu \mathrm{mol} \cdot \mathrm{L}^{-1} \text { EDTA equivalent }\right)\end{array}$ \\
\hline B_26 & KJ436568 & Serratia sp. & 99 & Enterobacteriales & $0.00 \pm 0.00$ \\
\hline B_32 & KJ436569 & Pseudomonas sp. & 99 & Pseudomonadales & $2.77 \pm 0.31^{* *}$ \\
\hline B_36 & KJ436571 & Pseudomonas sp. & 99 & Pseudomonadales & $1.07 \pm 0.15^{* *}$ \\
\hline B_29 & KP273839 & Bacillus sp. & 100 & Bacillales & $0.80 \pm 0.27^{* *}$ \\
\hline B_54 & KJ436572 & Bacillus sp. & 100 & Bacillales & $0.40 \pm 0.20$ \\
\hline B_05 & KP273842 & Paenibacillus sp. & 99 & Bacillales & $0.63 \pm 0.15^{* *}$ \\
\hline B_08 & KP273837 & Chromobacterium sp. & 98 & Neisseriales & $0.80 \pm 0.27^{* *}$ \\
\hline B_42 & KJ436572 & Janthinobacterium sp. & 100 & Burkholderiales & $1.33 \pm 0.15^{* *}$ \\
\hline B_33 & KJ436570 & Burkholderia sp. & 99 & Burkholderiales & $1.20 \pm 0.10^{* *}$ \\
\hline B_01 & KR349186 & Arthrobacter sp. & 99 & Actinomycetales & $1.15 \pm 0.10^{* *}$ \\
\hline
\end{tabular}

${ }^{* *}$ The value is highly significant $(\mathrm{p}<0.01)$; ${ }^{*}$ the value is significant $(\mathrm{p}<0.05)$. 
sonication as previously described [46] [47], was placed in an acid-washed $125 \mathrm{ml}$ glass Erlenmeyer culture flask and autoclaved at $121^{\circ} \mathrm{C}$ for $15 \mathrm{~min}$. The basalt was ground using a Tema swing mill, for 8 min, to a fraction size of less than $0.5 \mathrm{~mm}$ [47]. The specific surface area of the ground rock was measured using multi-point BET (Brunauer, Emmett and Teller, at Imperial College London) with $\mathrm{N}_{2}$ and yielded a surface area of 0.976 $\mathrm{m}^{2} \cdot \mathrm{g}^{-1}$. One hundred $\mathrm{mL}$ of liquid medium was added to the flask and the $\mathrm{pH}$ was adjusted to $\mathrm{pH} 7.0$ with 10 $\mathrm{mM} \mathrm{NaOH}$. Prior to inoculation, the isolates were grown in the modified minimal medium for five days. The cells were harvested by centrifugation at $4000 \times g$, for $5 \mathrm{~min}$, and the pellet was washed and resuspended (final cell density of $10^{7}$ to $10^{8}$ cell $\mathrm{mL}^{-1}$ ) in $50 \mathrm{mM}$ Tris buffer ( $\mathrm{pH} 7.0$ ). A $0.5 \%$ inoculum was used to inoculate the flasks. Abiotic controls were prepared in an identical manner to the biological flasks and the $\mathrm{pH}$ was adjusted with $\mathrm{HCl}$, each treatment was prepared in triplicate.

\subsection{Measuring Bacterial Growth}

To monitor bacterial growth and pH, $1 \mathrm{~mL}$ aliquots were aseptically removed after 1, 4, 7, 14, 21 and $28 \mathrm{~d}$. Cells were stained with the nucleic acid-binding dye SYBR Green I DNA $(0.1 \%$ w/v stock; Life Technologies, Paisley, UK) and filtered through a $0.2 \mu \mathrm{m}$ black polycarbonate filter and then washed with $100 \mu \mathrm{L}$ of sterile $\mathrm{ddH}_{2} \mathrm{O}$. The cells on the filter were enumerated using a Leica DMRP microscope equipped with epifluorescence, as previously described [58]. The growth rate constant $(k)$ for the log phase of growth was determined [49].

\subsection{Siderophore Production}

To determine the ability of the isolates to produce siderophores, the Chrome Azurol S liquid assay (CAS) was used [50]. The detection of siderophores was quantified and defined according to Payne [51]. The isolates were grown in the minimal medium, without iron (i.e. they were iron-limited), and siderophore production was measured in stationary stage cells. As a control we used Cupriavidus metallidurans CH34, which has previously been shown to produce siderophores under iron limiting conditions [46].

\subsection{Chemical Analyses}

The pH was measured using an Orion 3-Star Thermo Scientific bench top meter. The total concentration of dissolved elements was measured using ICP-MS (Agilent 7500s ICP-MS with New Wave 213 laser system) and the initial rate of elemental dissolution was calculated, as previously described [27]. Glucose concentration was measured using the Amplex red glucose kit (Invitrogen). The absorbance was measured at $595 \mathrm{~nm}$ and compared with a calibration curve of known glucose concentrations. Oxalate was measured using anoxalate oxidase assay (Trinity Biotech), at $590 \mathrm{~nm}$, as per manufacturer's instructions.

\subsection{FEG-SEM Analysis}

After $28 \mathrm{~d}$, rocks were removed from the flasks for FEG-SEM analysis. The rocks were air dried and carbon coated (15 - $20 \mathrm{~nm}$ thickness) on aluminium stubs. The surface of the rocks was examined using a Field Emission Gun (FEG)-SEM (ZEISS Supra; 55-VP; Zeiss Microimaging, Gottingen, Germany), which was operated with an accelerating voltage of $2-15 \mathrm{kV}$ and a 7 - $10 \mathrm{~mm}$ working distance.

\subsection{Statistical Analysis}

Statistical analysis was carried out using Open source R stat version 3.0.3 (R Development Core Team, 2010), using the Vegan Package [52]. Overall differences in taxa, at the four sample site, were compared using an ANOSIM test of difference [53]. Confirmation of the significance of any differences was identified using independent $t$-test. The ANOVA test in Microsoft Excel was used to determine a relationship between chemical dissolution and specific growth rates.

\section{Results}

\subsection{Composition of the Bacterial Community}

Partial sequencing of the 16S rRNA gene by Ion Torrent was used to identify the major bacterial classes. Quality filtration of the raw data resulted in a total of 276,571 sequences (median read length $180 \mathrm{bp}$ ). Of these se- 
quences, 1936 were identified as non-bacterial and were eliminated from further analysis. The sequences from each of the soil samples $(n=3)$ collected from of the sample sites were pooled. Each of the sample sites were represented by 74485 (Site 1), 76017 (Site 2), 72430 (Site 3) and 51703 (Site 4) bacterial sequences. The rarefaction curves suggested that the qualitative OTU ( $97 \%$ sequence similarity) richness, for each sample site, was high and did not appear to reach saturation (Figure 1).

Due to the sequence lengths the bacteria were identified at an order level. Taxonomical assignment of the sequences showed that over 40\% (84736 sequences) belonged to the orders Actinomycetales, Burkholderiales, Clostridales, Bacillales, Rhizobiales and Acidobacterium, as shown in Figure 2. At each of the sample sites

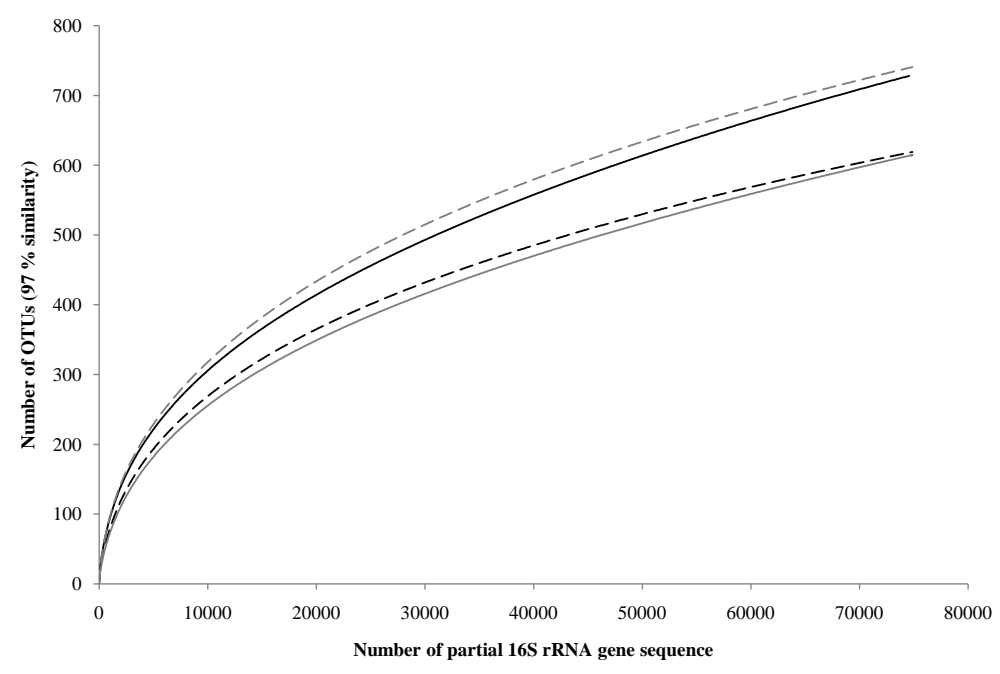

Figure 1. Rarefaction curves of the partial bacterial 16S rRNA gene sequences obtained from the interface between basaltic bedrock and nutrient poor soil, using Ion Torrent. The curves show the relationship between the increased number of bacterial OTUs ( $97 \%$ sequence similarity) and the number of randomly samples sequences from each sample site (Site $1(-)$; Site 2 (--); Site 3 (-) and Site $4(---))$.

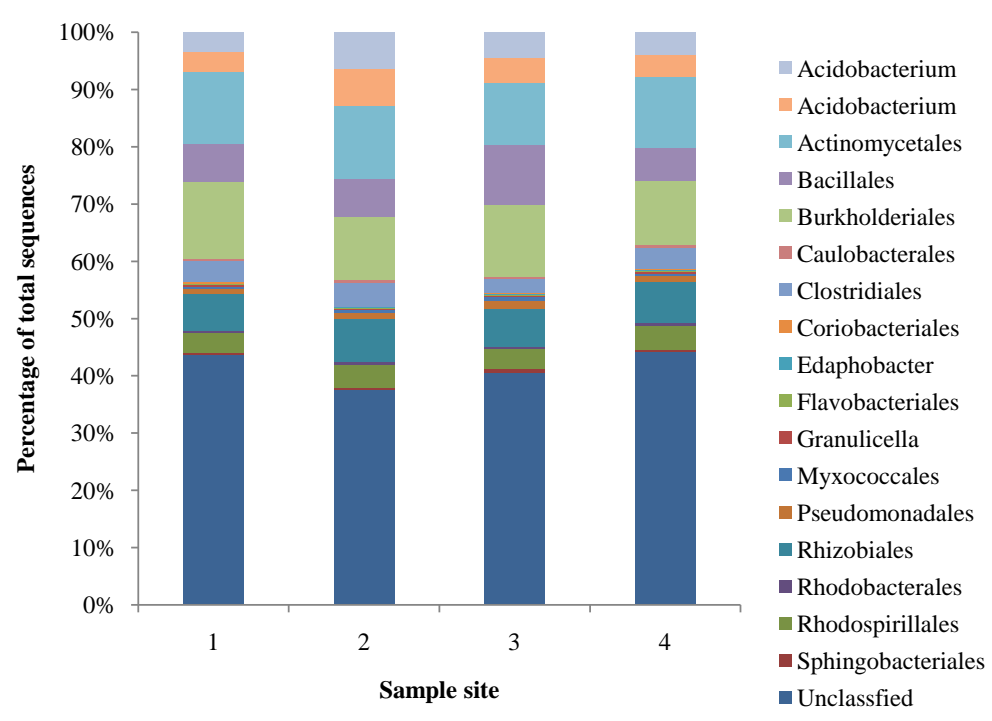

Figure 2. The relative abundance of the 17 most common bacterial orders identified at the interface between the basaltic bedrock and the nutrient limiting soil, at the four sample sites in Cadair Idris National Park, Snowdonia. Each sample was analysed in triplicate and the sequences for each sample site were pooled together. 
Burkholderiales and Actinomycetales were the most dominant. Burkholderiales represented between $10.91 \% \pm$ $1.04 \%$ (site 2) and $13.33 \% \pm 0.76 \%$ (site 1), and Actinomycetales represented between $10.94 \% \pm 1.55 \%$ (site 3) and $12.74 \% \pm 1.07 \%$ (site 2), of the bacterial community. The orders Bacillales and Rhizobiales each represented between $5.64 \% \pm 1.01 \%$ (Site 4 ) and $10.39 \% \pm 3.77 \%$ (Site 3) of the bacterial community; whilst Clostridales and Acidobacterium each represented between $2.61 \% \pm 0.76 \%$ (Site 3 ) and $6.45 \% \pm 1.43 \%$ (Site 2). The dataset consisted of $45.96 \% \pm 2.10 \%$ of unclassified sequences. The similarity of taxa between the four sample sites displayed no statistical differences when compared using an ANOSIM test of similarity $(\mathrm{R}=-0.067, p$ $=>0.05$ ).

\subsection{Bacterial Isolates}

Forty bacteria were isolated from the soil samples. Thirty three of the isolates belonged to the genera Pseudomonas and Bacillus and two of each were randomly selected for the dissolution experiment: B_32 and B_36 (Pseudomonas) and B_29 and B_54 (Bacillus). The other bacteria isolated from the soils belonged to the genera Serratia (B_26), Paenibacillus (B_05) Chromobacterium (B_08) Janthinobacterium (B_42), Burkholderia (B_33) and Arthrobacter (B_01) as demonstrated in Table 2. Each of the isolates listed in Table 2 were screened for siderophore production using the Chrome Azurol S assay. In the minimal medium, without iron, eight of the isolates produced siderophores $\left(p<0.05\right.$ ), as shown in Table 2. However, in the glucose- $\mathrm{NH}_{4}$ medium with basalt we were unable to detect any siderophore production (data not shown).

\subsection{Bacterial Growth}

Each of the ten isolates listed in Table 2 were able to grow in the glucose- $\mathrm{NH}_{4}$ medium with basalt (no growth was detected in the growth medium without basalt). Cells were located in the growth medium and on the surface of the basalt, as shown in Figure 3. All of the bacteria utilised the glucose and within 7 days the concentration of glucose had decreased to approximately $20 \%$ (data not shown). As the isolates utilised the glucose the metabolite oxalate was produced. As shown in Figure 4, the concentration of oxalate increased over time, for example the amount produced by B_08 increased from $58 \mu \mathrm{M}$ (day 1) to $85 \mu \mathrm{M}$ (day 28). The concentration of oxalate produced varied between the isolates, for example the amount of oxalate produced by B_26, B_05, B_01 and B_08 was below $30 \mu \mathrm{M}$. The specific growth rate also varied between the isolates and the results suggest a relationship between the production of oxalate and specific growth rate. For example, the specific growth rate for B_54 was $0.64 \pm 0.23 \mathrm{~d}^{-1}$ and the maximum amount of oxalate that the isolate produced was $96 \mu \mathrm{M}$; whereas, the specific growth rate of $B_{-} 01$ was $0.14 \pm 0.03 \mathrm{~d}^{-1}$ and the maximum amount of oxalate produced was $25 \mu \mathrm{M}$.

\section{4. pH Change}

The $\mathrm{pH}$ of the unbuffered growth medium was monitored throughout the experiment. Acidification occurred during exponential growth, but the extent varied between the isolates, for example, a $\mathrm{pH}$ drop to 5.7 was observed for isolate B_36; whilst a pH decrease to 3.0 was observed for isolate B_32. For 7 of the isolates (B_30, B_32, B_ 36, B_03, B_54, B_57, and B_42), the pH dropped rapidly during exponential growth to between 3.0 and 3.8, and then increased to steady-state equilibrium of between $\mathrm{pH} 6.8$ and 7.1, as shown in Figure 5. The greatest decrease in $\mathrm{pH}$ was observed with $\mathrm{B} \_32$ (pH 3.0). For the abiotic controls, without cells, the pH of the medium was measured as between 6.8 and 7.0 throughout the experiment.

\subsection{Basalt Dissolution}

Dissolution was measured by the release of key elements ( $\mathrm{Si}, \mathrm{K}, \mathrm{Ca}$ and $\mathrm{Mg}$ ) into the growth medium. From these values, the linear elemental release rates $\left(R_{i}^{l}\right)$ from the initial part of the experiment were calculated. As shown in Table 3, the $R_{i}^{l}$ values varied between the isolates, for example, the $R_{i}^{l}$ value for Si ranged from $3.29 \pm 0.22 \times 10^{-12} \mathrm{~mol} \cdot \mathrm{m}^{-2} \cdot \mathrm{s}^{-1}$ (B_54) to $1.02 \pm 0.10 \times 10^{-12} \mathrm{~mol} \cdot \mathrm{m}^{-2} \cdot \mathrm{s}^{-1}$ (B_08). Compared to the abiotic control, dissolution of $\mathrm{Si}, \mathrm{K}, \mathrm{Ca}$ and $\mathrm{Mg}$, were significantly enhanced by seven of the isolates $(p<0.05)$, as shown in Table 3. A Person's product-moment correlation demonstrated a correlation between the $R_{i}^{l}$ values for Mg $(p \leq 0.001)$, Ca $(p \leq 0.001), \mathrm{Si}(p \leq 0.001)$ and $\mathrm{K}(p \leq 0.001)$ and the specific growth rates. For example, the relationship between the $R_{i}^{l}$ values for $\mathrm{Si}$ and the growth rates is shown in Figure 6(A). On further analysis, a 

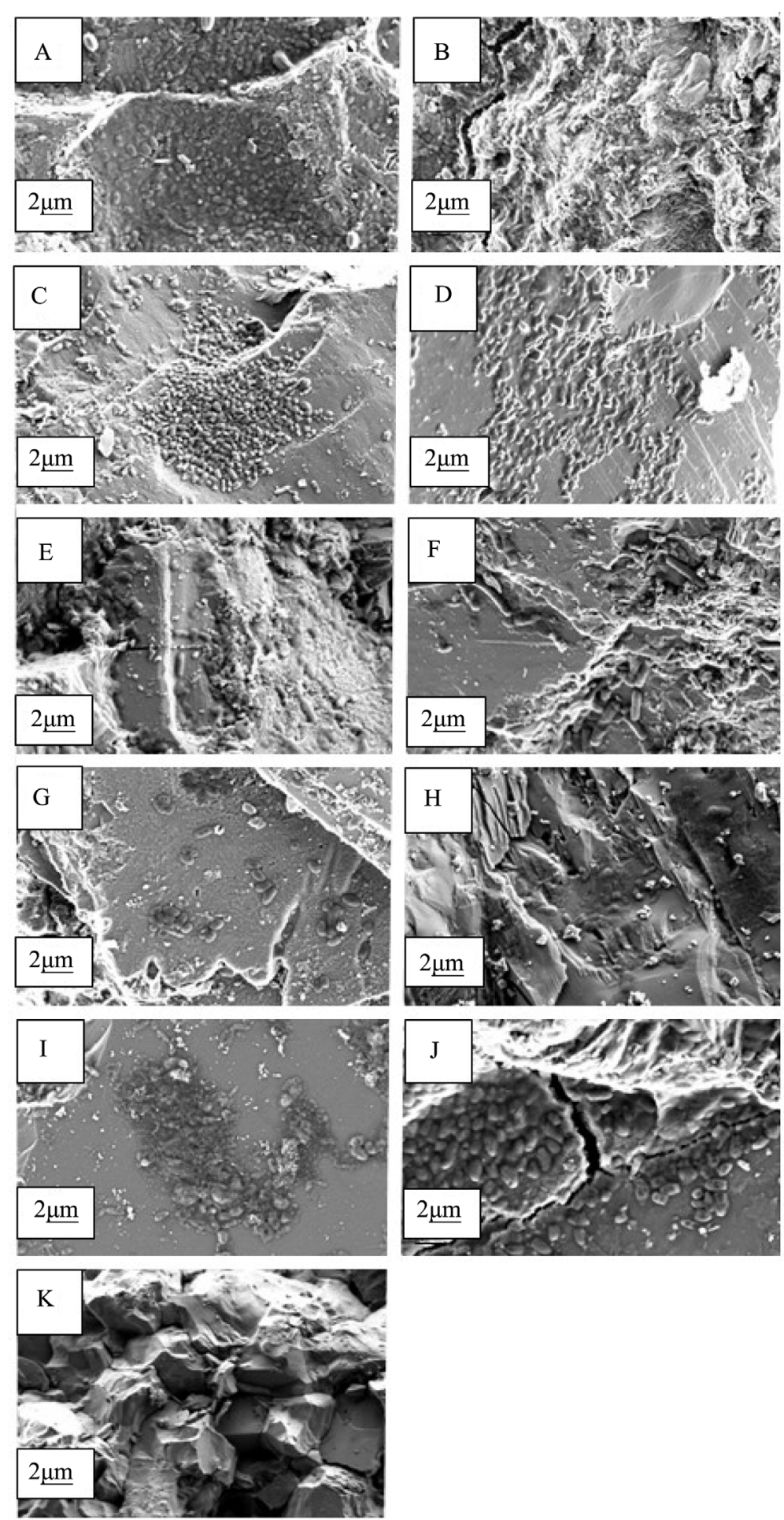

Figure 3. FEG-SEM micrograph of the isolates on the surface of the basalt: A (B_26), B (B_32), C (B_36), D (B_29), E (B_54), F (B_05), G (B_08), H (B_42), I (B_33), J (B_01) and K (abiotic control).

clear relationship was demonstrated between $\mathrm{pH}$ and the $R_{i}^{l}$ values for $\mathrm{Mg}(p \leq 0.001)$, Ca $(p \leq 0.001)$, $\mathrm{Si}(p \leq$ $0.001)$ and $\mathrm{K}(p \leq 0.001)$. For example, the relationship between the $R_{i}^{l}$ values for $\mathrm{Si}$ and $\mathrm{pH}$ is shown in Figure 6(B); however, it is difficult to determine if this is mediated by protons or organic ligands, because a rela- 


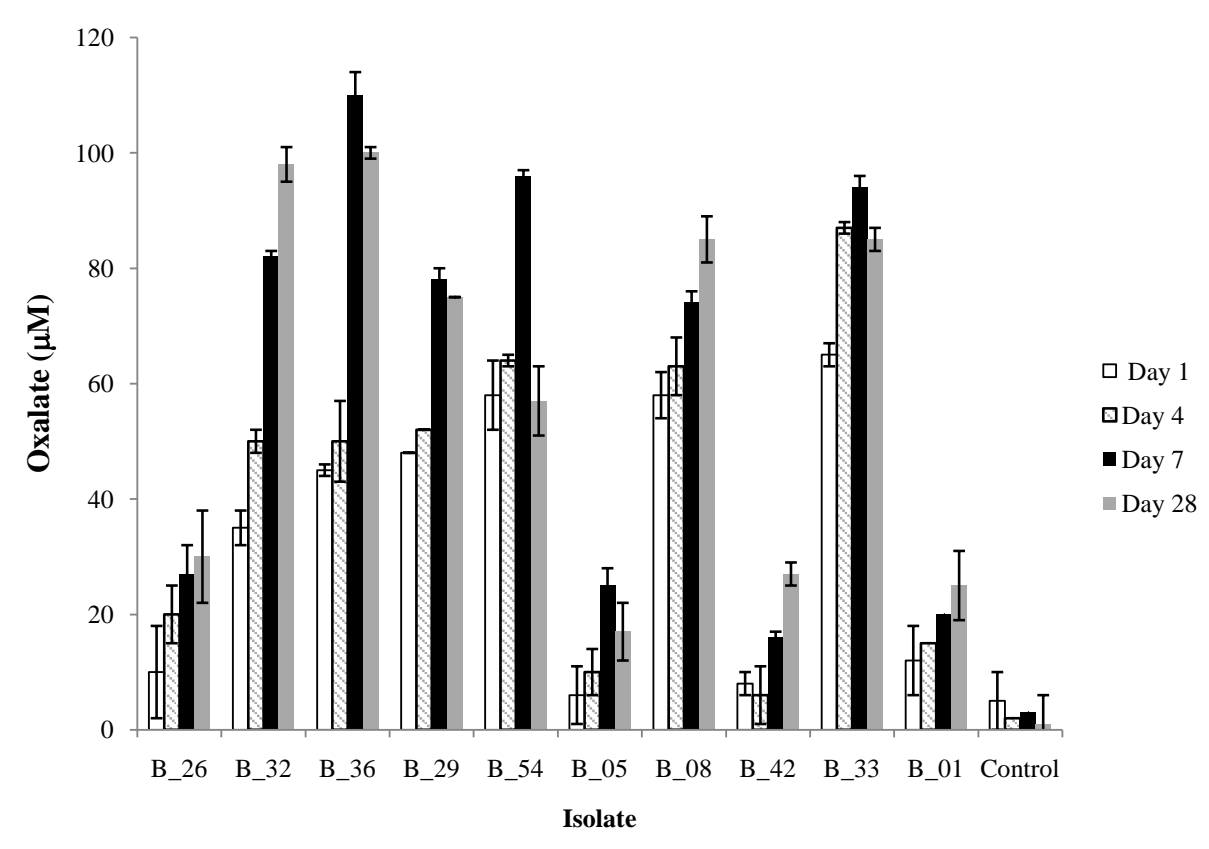

Figure 4. Concentration of oxalate in the growth medium after 1, 4, 7 and 28 days. The values reported are the means of three independent experiments, and the standard error associated with these determinations is shown.

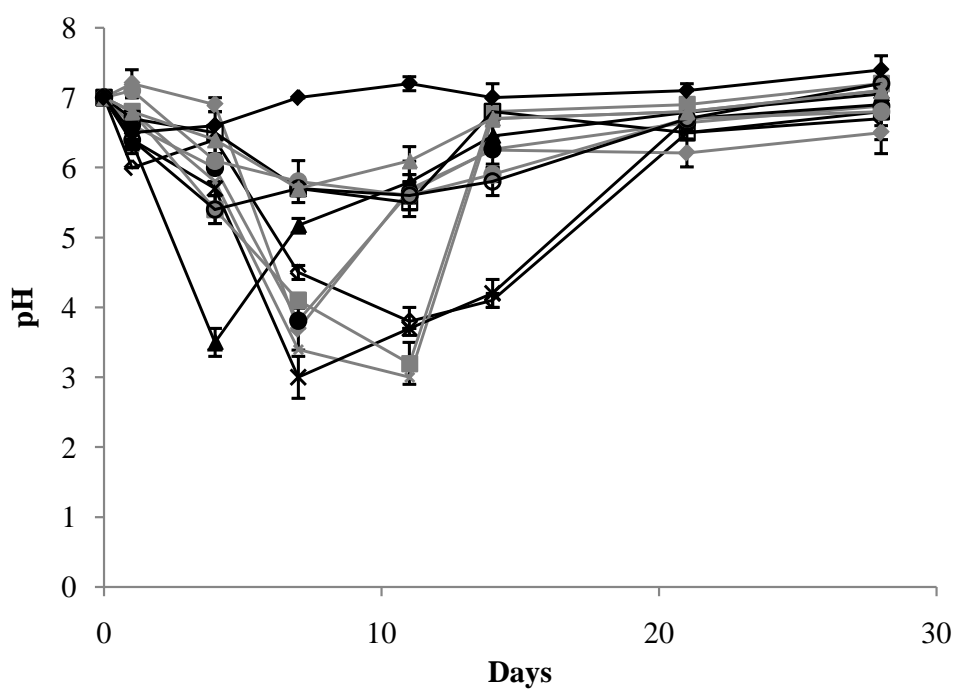

Figure 5. Change in $\mathrm{pH}$ of the medium over time for each of the isolates: B_26 ( $\square$ ); B_32 $(\diamond) ; B \_36 ;(\times)$; B_08 $(\diamond) ;$ B_54 $(\Delta)$; B_29 $(\bullet)$; B_33 $(\triangle)$; B_05( $\left.\square\right)$; B_42 $(\bigcirc)$; B_01 $(\bigcirc)$ and abiotic control $(\diamond)$. Cell counts demonstrated that there was no bacterial contamination in the abiotic controls, after 28 days. The values reported are the means of three independent experiments, and the standard error associated with these determinations is shown.

tionship was also demonstrated between oxalate production and the $R_{i}^{l}$ values for $\mathrm{Mg}(p \leq 0.001)$, Ca ( $p \leq$ $0.001)$, $\mathrm{Si}(p \leq 0.001)$ and K $(p \leq 0.001)$. The correlation between oxalate and the $R_{i}^{l}$ values for Si dissolution is shown in Figure 6(C).

\section{Discussion}

The focus of this study was the microbial community at the interface between basaltic bedrock and nutrient limi- 
Table 3. Biotic and abiotic mediated linear release rates of Si, K, Ca and Mg dissolution.

\begin{tabular}{cccccc}
\hline & & \multicolumn{3}{c}{ Dissolution rate $\left(\mathbf{1 0}^{-\mathbf{1 2}} \mathbf{m o l}^{\left.\cdot \mathbf{m}^{-2} \cdot \mathbf{s}^{-1}\right)}\right.$} \\
\hline Isolates & Specific growth rate $\left.\mathbf{( d}^{-\mathbf{1}}\right)$ & $\mathbf{M g}$ & $\mathbf{S i}$ & $\mathbf{K}$ & Ca \\
\hline B_26 & $0.09 \pm 0.02$ & $1.18 \pm 0.23$ & $1.32 \pm 0.11^{*}$ & $0.87 \pm 0.05$ & $1.49 \pm 0.47$ \\
B_32 & $0.54 \pm 0.07$ & $2.14 \pm 0.14^{* *}$ & $2.10 \pm 0.23^{* *}$ & $1.72 \pm 0.23^{* *}$ & $2.70 \pm 0.20^{* *}$ \\
B_36 & $0.55 \pm 0.09$ & $2.65 \pm 0.13^{* *}$ & $2.11 \pm 0.45^{*}$ & $1.99 \pm 0.02^{* *}$ & $1.75 \pm 0.08^{*}$ \\
B_29 & $0.34 \pm 0.13$ & $1.68 \pm 0.17^{* *}$ & $2.14 \pm 0.25^{* *}$ & $1.7 \pm 0.20^{* *}$ & $1.57 \pm 0.33^{* *}$ \\
B_54 & $0.64 \pm 0.23$ & $2.18 \pm 0.42^{* *}$ & $3.29 \pm 0.22^{* *}$ & $1.65 \pm 0.38^{* *}$ & $1.70 \pm 0.15^{* *}$ \\
B_5 & $0.10 \pm 0.23$ & $1.33 \pm 2.18$ & $1.19 \pm 0.17$ & $0.96 \pm 0.08^{*}$ & $1.47 \pm 0.36^{*}$ \\
B_8 & $0.08 \pm 0.01$ & $1.38 \pm 0.38$ & $1.02 \pm 0.10$ & $0.86 \pm 0.06^{*}$ & $1.49 \pm 0.11^{*}$ \\
B_42 & $0.36 \pm 0.14$ & $1.72 \pm 0.24^{* *}$ & $1.92 \pm 0.13^{* *}$ & $1.11 \pm 0.13^{* *}$ & $1.39 \pm 0.24^{* *}$ \\
B_33 & $0.25 \pm 0.08$ & $1.62 \pm 0.25^{*}$ & $1.73 \pm 0.16^{* *}$ & $1.06 \pm 0.06^{*}$ & $1.75 \pm 0.47^{* *}$ \\
B_01 & $0.14 \pm 0.03$ & $1.27 \pm 0.17^{*}$ & $1.66 \pm 0.09^{* *}$ & $1.05 \pm 0.06^{* *}$ & $1.39 \pm 0.39^{* *}$ \\
Abiotic control & & $0.98 \pm 0.03$ & $1.05 \pm 0.06$ & $0.80 \pm 0.06$ & $1.03 \pm 0.36$ \\
\hline
\end{tabular}

${ }^{* * *}$ The value is highly significant $(p<0.01)$; ${ }^{*}$ the value is significant $(p<0.05)$.

ting soils. Samples were collected from below any visible root systems, which reduced the direct influence of the above ground vegetation and the associated rhizosphere bacterial community, which have been shown to influence mineral weathering [18] [54]-[58].

In the sequence database, the major bacterial orders were Actinomycetales and Burkholderiales, which represented approximately $25 \%$ of the total sequences (62,500 sequences). Both of these orders are common in soil, including mineral rich basaltic soils [26] [36] [59]-[61]. Actinomycetales was shown to be the dominant order in weathered basaltic outcrops in Iceland, in mineral rich volcanic soils surrounding Mount Helens volcano in the USA and within non-fumarole soil near the Socompa Volcano, Argentina [36] [59]. Furthermore, Beta-proteobacteria, which includes the order Burkholderiales was shown to be the dominate class in six year old bacterial communities on volcanic basalt deposits in Hawaii and the genus Herbaspirilum, which belongs to the order Burkholderiales, has been isolated from volcanic mountain soils [60] [61].

Linking diversity to mineral weathering requires culturing members of the bacterial community to investigate their weathering potential [8] [62]. The isolation procedure that was used in this study selected for heterotrophic aerobes, which resulted in members of the genera Pseudomonas, Bacillus, Paenibacillus, Serratia, Janthinobacterium, Burkholderia, Arthrobacter and Chromobacterium being isolated. In batch culture experiments, all of the isolates were able to grow using only basalt as the sole source of bio-essential elements. Seven of the isolates Burkholderia (B_33 and B_42), Pseudomonas (B_32 and B_36), Janthinobacterium (B_42), Arthrobacter (B_01) and Bacillus (B_29) significantly enhanced the release of elements from the basalt. Members of these genera have previously been shown to weather minerals [18] [30] [57] [63]-[66]. For example, an Arthobacter sp. and a Janthinobacterium sp. isolated from the Damma Glacier forefield were able to significantly enhanced granite weathering in laboratory experiments [30]. Members of the genera Bacillus and Pseudomonas have been shown to enhance the dissolution of insoluble phosphate [63]. Furthermore, in nutrient limiting forest soil, Uroz et al., [31] [35] demonstrated a potential correlation between the abundance of the genus Burkholderia and the rate of apatite, plagioclase and phlogopite-quartz dissolution.

Under nutrient limiting conditions, bacteria have been shown to produce siderophores, which are known to enhance the rate of iron-oxide and iron-silicate dissolution by approximately one order of magnitude [67]-[69]. We were unable to measure siderophore production for any of the isolates in the basalt medium; however, when they were grown in minimal medium, without basalt, we were able to measure significant amounts of siderophore production with ten of the isolates. This is in agreement with previous studies, which have been unable to measure siderophore production in the presence of basalt or granite [30] [46]. Olsson-Francis et al., proposed that siderophore production was inhibited by basalt, in batch culture, because the iron was leached from the ba- 


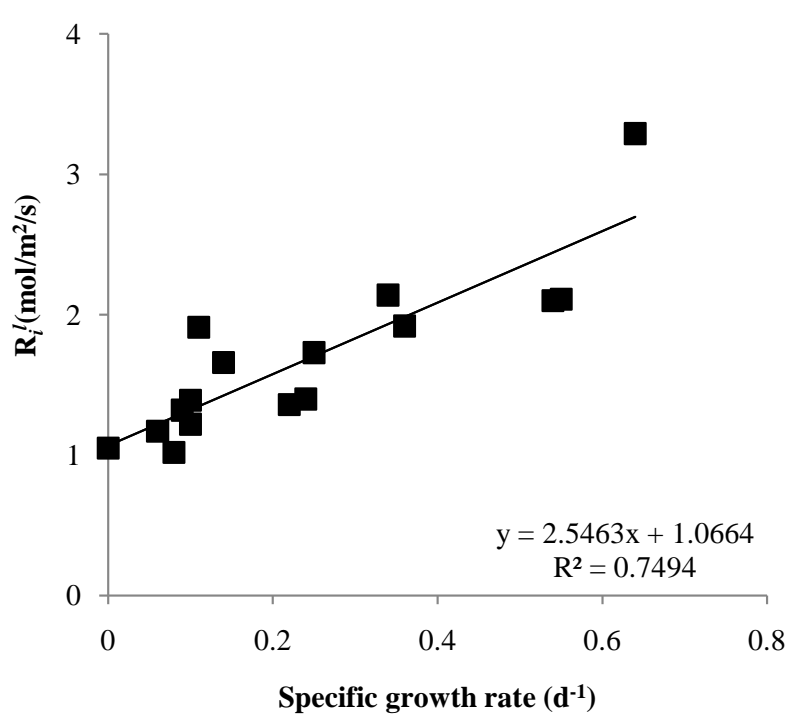

(A)

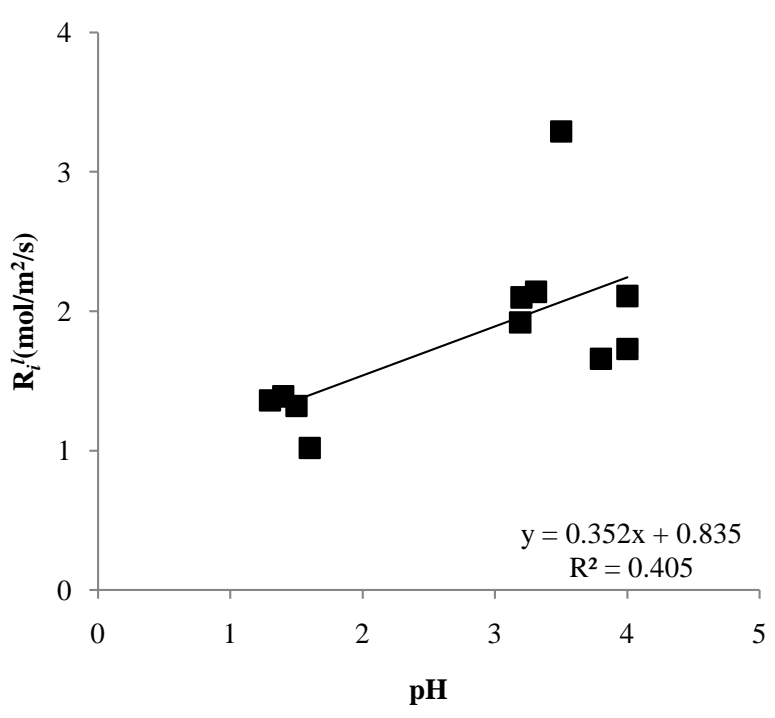

(B)

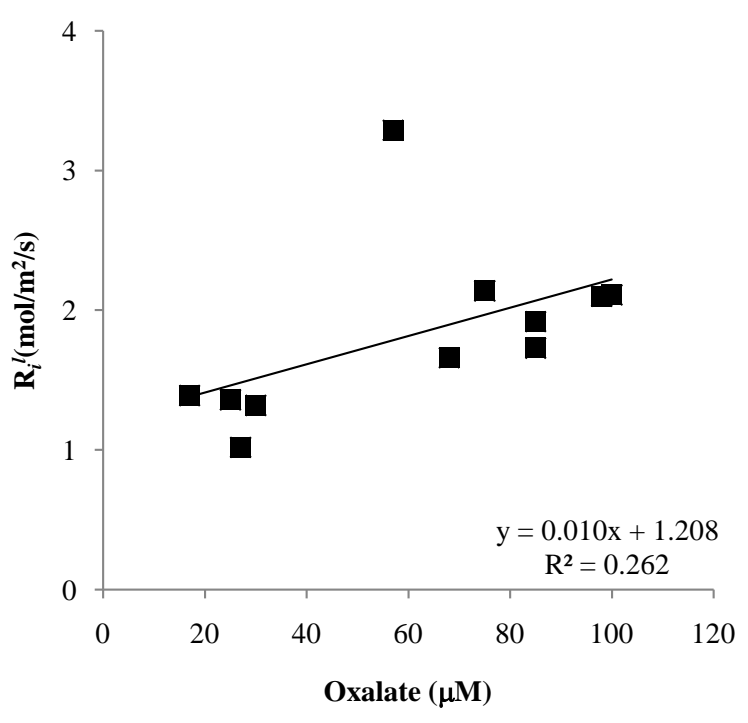

(C)

Figure 6. $\log R_{i}^{l}$ values for Si versus (A) specific growth rate; (B) $\mathrm{pH}$ and (C) oxalate, for each of the bacterium. The specific growth rates corresponded to the following bacterium: B_26, $0.09 \mathrm{~d}^{-1}$; B_32,0.54d $\mathrm{d}^{-1}$; B_36, $0.55 \mathrm{~d}^{-1}$; B_29, $0.34 \mathrm{~d}^{-1}$; B_54, $0.64 \mathrm{~d}^{-1}$; B_05, $0.10 \mathrm{~d}^{-1}$; B_08, $0.08 \mathrm{~d}^{-1}$; B_42, $0.36 \mathrm{~d}^{-1}$; B_33, $0.25 \mathrm{~d}^{-1}$; B_01, $0.14 \mathrm{~d}^{-1}$. The R value was determined using a Person's product-moment correlation.

salt in an aqueous state $\left(\mathrm{Fe}^{2+}\right)$ making it accessible for bacteria to use; therefore not requiring siderophore production for iron uptake [46].

Heterotrophic bacteria are also known to increase mineral dissolution by acidification either through organic acids or proton-promotion [70] [71]. Several organic acids, such as acetate, gluconic acid, citrate and oxalate have been shown to enhance weathering [72]-[75]. In this study we demonstrated a correlation between the concentration of oxalate in the growth medium and basalt dissolution. Oxalate acts as a ligand, which directly affects mineral dissolution by complexing metal ions at the surface and therefore assisting the release of metals through ligand-promoted dissolution [74]. Although it is difficult to distinguish between organic ligands and proton-mediated dissolution, previous studies have suggested that the initial effect of microbial mediated weathering is due to organic ligand protonated dissolution and secondarily through acidification [30].

While it has been postulated that the concentration of organic acids in the soil is insufficient to cause mineral 
dissolution, bacteria produce extracellular polysaccharides, which allow them to attach to the surface of the rock producing a microenvironment where organic acids are concentrated [71] [72]. Microcosm experiments have demonstrated a correlation between surface cell density and dissolution rates with granite [30]. Although, we demonstrated that each of the isolates formed a layer on the surface of the rock, in batch culture it is difficult to determine if this was due to attachment or the flasks being stationary.

\section{Conclusion}

The results from this study suggest that at the interface between bedrock and soil, heterotrophic bacteria can enhance mineral weathering, therefore, playing a part in biogeochemical cycling. Future work is required to understand the mechanism that bacteria employ to sequester bio-essential elements in the natural environment, particularly in the microenvironment surrounding the rock. This would be important for further understanding the regulation of biogeochemical cycling in nutrient limiting soils.

\section{Acknowledgements}

This work was funded by the UK Space Agency as part of an individual fellowship awarded to Olsson-Francis. We would like to thank Natural Resources Wales for allowing sampling within Snowdonia National Park.

\section{References}

[1] Mortatti, J. and Probst, J.L. (2003) Silicate Rock Weathering and Atmospheric/Soil $\mathrm{CO}_{2}$ Uptake in the Amazon Basin Estimated from River Water Geochemistry: Seasonal and Spatial Variations. Chemical Geology, 197, 177-196. http://dx.doi.org/10.1016/S0009-2541(02)00349-2

[2] Holland, H.D., Lazar, B. and McCaffrey, M. (1986) Evolution of the Atmosphere and Oceans. Nature, 320, 27-33. http://dx.doi.org/10.1038/320027a0

[3] Kump, L.R., Brantley, S.L. and Arthur, M.A. (2000) Chemical, Weathering, Atmospheric $\mathrm{CO}_{2}$, and Climate. Annual Review of Earth and Planetary Sciences, 28, 611-67. http://dx.doi.org/10.1146/annurev.earth.28.1.611

[4] Wolff-Boenisch, D., Gislason, S.R. and Oelkers, E.H. (2006) The Effect of Crystallinity on Dissolution Rates and $\mathrm{CO}_{2}$ Consumption Capacity of Silicates. Geochimica et Cosmochimica Acta, 70, 858-870. http://dx.doi.org/10.1016/j.gca.2005.10.016

[5] Drever, J.I. (1994) The Effect of Land Plants on Weathering Rates of Silicate Minerals. Geochimica et Cosmochimica Acta, 58, 2325-2332. http://dx.doi.org/10.1016/0016-7037(94)90013-2

[6] Suchet, P.A., Probst, J.L. and Ludwig, W. (2003) Worldwide Distribution of Continental Rock Lithology: Implications for the Atmospheric/Soil $\mathrm{CO}_{2}$ Uptake by Continental Weathering and Alkalinity River Transport to the Oceans. Global Biogeochemical Cycles, 17, 45-56.

[7] Dessert, C., Dupre, B., Gaillardet, J., Francois, L.M. and Allegre, C.J. (2003) Basalt Weathering Laws and the Impact of Basalt Weathering on the Global Carbon Cycle. Chemical Geology, 202, 257-273. http://dx.doi.org/10.1016/j.chemgeo.2002.10.001

[8] Lepleux, C., Uroz, S., Collignon, C., Churin, J.L., Turpault, M.P. and Frey-Klett, P. (2013) A Short-Term Mineral Amendment Impacts the Mineral Weathering Bacterial Communities in an Acidic Forest Soil. Research in Microbiology, 164, 729-739. http://dx.doi.org/10.1016/j.resmic.2013.03.022

[9] Jenny, H. (1980) The Soil Resource: Origins and Behaviour. Spinger-Verlag, Berlin. http://dx.doi.org/10.1007/978-1-4612-6112-4

[10] Buol, S.W., Hole, F.D. and McCracken R.J. (1989) Soil Genesis and Classification. Iowa State University Press, Ames.

[11] Huggett, R.J. (1995) Geoecology: An Evolutionary Approach. Routledge, London. http://dx.doi.org/10.4324/9780203307373

[12] Brantley, S.L., Lebedeva, M. and Hausrath, E.M. (2012) A Geobiological View of Weathering and Erosion. In: Knoll, A.H., Cranfield, D.E. and Konhauser, K.O., Eds., Fundamentals of Geobiology, Blackwell, Oxford, 205-227. http://dx.doi.org/10.1002/9781118280874.ch12

[13] Schwartzman, D.W. (2010) Coevolution of the Biosphere and Climate. In: Jorgensen, S.E. and Fath, B.D., Eds., Global Ecology, Elsevier, Oxford, 648-658.

[14] Berner, E.K., Berner, R.A. and Moulton, K.L. (2004) Plants and Mineral Weathering: Past and Present. Elsevier, Amsterdam.

[15] Martino, E. and Perotto, S. (2010) Mineral Transformations by Mycorrhizal Fungi. Geomicrobiology Journal, 27, 609- 
623. http://dx.doi.org/10.1080/01490451003702958

[16] Sokolova, T.A. (2011) The Role of Soil Biota in the Weathering of Minerals: A Review of Literature. Eurasian Soil Science, 44, 56-72. http://dx.doi.org/10.1134/S1064229311010121

[17] Calvaruso, C., Turpault, M.P. and Frey-Klett, P. (2006) Root-Associated Bacteria Contribute to Mineral Weathering and to Mineral Nutrition in Trees: A Budgeting Analysis. Applied and Environmental Microbiology, 72, 1258-1266. http://dx.doi.org/10.1128/AEM.72.2.1258-1266.2006

[18] Uroz, S., Calvaruso, C., Turpault, M.P. and Frey-Klett, P. (2009) Mineral Weathering by Bacteria: Ecology, Actors and Mechanisms. Trends in Microbiology, 17, 378-387. http://dx.doi.org/10.1016/j.tim.2009.05.004

[19] Rogers, J.R. and Bennett, P.C. (2004) Mineral Stimulation of Subsurface Microorganisms: Release of Limiting Nutrients from Silicates. Chemical Geology, 203, 91-108. http://dx.doi.org/10.1016/j.chemgeo.2003.09.001

[20] Carson, J.K., Rooney, D., Gleeson, D.B. and Clipson, N. (2007) Altering the Mineral Composition of Soil Causes a Shift in Microbial Community Structure. FEMS Microbiology Ecology, 61, 414-423. http://dx.doi.org/10.1111/j.1574-6941.2007.00361.x

[21] Uroz, S., Turpault, M.P., Delaruelle, C., Mareschal, L., Pierrat, J.C. and Frey-Klett, P. (2012) Minerals Affect the Specific Diversity of Forest Soil Bacterial Communities. Geomicrobiology Journal, 29, 88-98. http://dx.doi.org/10.1080/01490451.2010.523764

[22] Santelli, C.M., Edgcomb, V.P., Bach, W. and Edwards, K.J. (2009) The Diversity and Abundance of Bacteria Inhabiting Seafloor Lavas Positively Correlate with Rock Alteration. Environmental Microbiology, 11, 86-98. http://dx.doi.org/10.1111/j.1462-2920.2008.01743.x

[23] Gleeson, D.B., Kennedy, N.M., Clipson, N., Melville, K., Gadd, G.M. and McDermott, F.P. (2006) Characterization of Bacterial Community Structure on a Weathered Pegmatitic Granite. Microbial Ecology, 51, 526-534. http://dx.doi.org/10.1007/s00248-006-9052-x

[24] Hutchens, E., Gleeson, D., McDermott, F., Miranda-CasoLuengo, R. and Clipson, N. (2010) Meter-Scale Diversity of Microbial Communities on a Weathered Pegmatite Granite Outcrop in the Wicklow Mountains, Ireland; Evidence for Mineral Induced Selection? Geomicrobiology Journal, 27, 1-14. http://dx.doi.org/10.1080/01490450903232157

[25] Lepleux, C., Turpault, M.P., Oger, P., Frey-Klett, P. and Uroz, S. (2012) Correlation of the Abundance of Betaproteobacteria on Mineral Surfaces with Mineral Weathering in Forest Soils. Applied and Environmental Microbiology, 78, 7114-7119. http://dx.doi.org/10.1128/AEM.00996-12

[26] Cockell, C.S., Kelly, L.C. and Marteinsson, V. (2013) Actinobacteria: An Ancient Phylum Active in Volcanic Rock Weathering. Geomicrobiology Journal, 30, 706-720. http://dx.doi.org/10.1080/01490451.2012.758196

[27] Olsson-Francis, K., Simpson, A.E., Wolff-Boenisch, D. and Cockell, C.S. (2012) The Effect of Rock Composition on Cyanobacterial Weathering of Crystalline Basalt and Rhyolite. Geobiology, 10, 434-444. http://dx.doi.org/10.1111/j.1472-4669.2012.00333.x

[28] Wu, L., Jacobson, A.D., Chen, H.C. and Hausner, M. (2007) Characterization of Elemental Release during MicrobeBasalt Interactions at $T=28{ }^{\circ} \mathrm{C}$. Geochimica et Cosmochimica Acta, 71, 2224-2239. http://dx.doi.org/10.1016/j.gca.2007.02.017

[29] Wu, L., Jacobson, A.D. and Hausner, M. (2008) Characterization of Elemental Release during Microbe-Granite Interactions at $T=28^{\circ} \mathrm{C}$. Geochimica et Cosmochimica Acta, 72, 1076-1095. http://dx.doi.org/10.1016/j.gca.2007.11.025

[30] Frey, B., Rieder, S.R., Brunner, I., Plotze, M., Koetzsch, S. and Lapanje, A. (2010) Weathering-Associated Bacteria from the Damma Glacier Forefield: Physiological Capabilities and Impact on Granite Dissolution. Applied and Environmental Microbiology, 76, 4788-4796. http://dx.doi.org/10.1128/AEM.00657-10

[31] Bardgett, R. and Leemans, D. (1996) Soil Microbial Activity on Exposed Mountain Ridges in Snowdonia (Eryri), North Wales. Soil Biology and Biochemistry, 28, 1533-1536. http://dx.doi.org/10.1016/S0038-0717(96)00145-9

[32] Schofield, P.F., Knight, K.S., Covery-Crump, S.J., Cressey, G. and Stretton, I.C. (2002) Accurate Quantification of the Model Minerology of Rocks When Image Analysis Is Difficult. Mineralogical Magazine, 66, 189-200. http://dx.doi.org/10.1180/0026461026610022

[33] Kalra, Y.P., Agrawal, H.P., Allen, E., Ashworth, J., Audesse, P., Case, V.W., et al. (1995) Determination of pH of Soils by Different Methods: Collaboative Study. Journal of AOAC International, 78, 310-324.

[34] Griffiths, R.I., Whiteley, A.S., O’Donnell, A.G. and Bailey, M.J. (2000) Rapid Method for Coextraction of DNA and RNA from Natural Environments for Analysis of Ribosomal DNA- and rRNA-Based Microbial Community Composition. Applied and Environmental Microbiology, 66, 5488-5491. http://dx.doi.org/10.1128/AEM.66.12.5488-5491.2000

[35] Whiteley, A.S., Jenkins, S., Waite, I., Kresoje, N., Payne, H., Mullan, B., et al. (2012) Microbial 16S rRNA Ion Tag and Community Metagenome Sequencing Using the Ion Torrent (PGM) Platform. Journal of Microbiological Methods, 91, 80-88. http://dx.doi.org/10.1016/j.mimet.2012.07.008 
[36] Costello, E.K., Lauber, C.L., Hamady, M., Fierer, N., Gordon, J.I. and Knight, R. (2009) Bacterial Community Variation in Human Body Habitats across Space and Time. Science, 326, 1694-1697. http://dx.doi.org/10.1126/science.1177486

[37] Edgar, R.C., Haas, B.J., Clemente, J.C., Quince, C. and Knight, R. (2011) UCHIME Improves Sensitivity and Speed of Chimera Detection. Bioinformatics, 27, 2194-2200. http://dx.doi.org/10.1093/bioinformatics/btr381

[38] Pruesse, E., Quast, C., Knittel, K., Fuchs, B.M., Ludwig, W.G., Peplies, J., et al. (2007) SILVA: A Comprehensive Online Resource for Quality Checked and Aligned Ribosomal RNA Sequence Data Compatible with ARB. Nucleic Acids Research, 35, 7188-7196. http://dx.doi.org/10.1093/nar/gkm864

[39] Wang, Q., Garrity, G.M., Tiedje, J.M. and Cole, J.R. (2007) Naive Bayesian Classifier for Rapid Assignment of rRNA Sequences into the New Bacterial Taxonomy. Applied and Environmental Microbiology, 73, 5261-5267. http://dx.doi.org/10.1128/AEM.00062-07

[40] Schloss, P.D., Westcott, S.L., Ryabin, T., Hall, J.R., Hartmann, M., Hollister, E.B., et al. (2009) Introducing MOTHUR: Open-Source, Platform-Independent, Community-Supported Software for Describing and Comparing Microbial Communities. Applied and Environmental Microbiology, 75, 7537-7541. http://dx.doi.org/10.1128/AEM.01541-09

[41] Meyer, F., Paarmann, D., D’Souza, M., Olson, R., Glass, E.M., Kubal, M., et al. (2008) The Metagenomics RAST Server-A Public Resource for the Automatic Phylogenetic and Functional Analysis of Metagenomes. BMC Bioinformatics, 9, 386. http://dx.doi.org/10.1186/1471-2105-9-386

[42] Schwieger, F. and Tebbe, C.C. (1998) A New Approach to Utilize PCR Single Strand Conformation Polymorphism for 16s rRNA Gene-Based Microbial Community Analysis. Applied and Environmental Microbiology, 64, 4870-4876.

[43] Lane, D.J. (1991) rRNA Sequencing. John Wiley and Sons, New York.

[44] Embley, T.M. (1991) The Linear PCR Reaction: A Simple and Robust Method for Sequencing Amplified Ribosomal rRNA Genes. Letters in Applied Microbiology, 13, 171-174. http://dx.doi.org/10.1111/j.1472-765X.1991.tb00600.x

[45] Altschul, S.F., Gish, W., Miller, W., Myers, E.W. and Lipman, D.J. (1990) Basic Local Alignment Search Tool. Journal of Molecular Biology, 215, 403-410. http://dx.doi.org/10.1016/s0022-2836(05)80360-2

[46] Olsson-Francis, K., Van Houdt, R., Mergeay, M., Leys, N. and Cockell, C.S. (2010) Microarray Analysis of a Microbe-Mineral Interaction. Geobiology, 8, 446-456. http://dx.doi.org/10.1111/j.1472-4669.2010.00253.x

[47] Olsson-Francis, K., de la Torre, R. and Cockell, C.S. (2010) Exposure of a Rock-Dwelling Cyanobacteria Community to Low Earth Orbit. Origins of Life and Evolution of Biospheres, 40, 540-541.

[48] Summers, S., Whiteley, A.S., Kelly, L. and Cockell, C.S. (2013) Land Coverage Influences the Bacterial Community Composition in the Critical Zone of a Sub-Artic Basaltic Environment. FEMS Microbiology Ecology, 86, 381-393. http://dx.doi.org/10.1111/1574-6941.12167

[49] Pirt, S.J. (1978) Principles of Microbe and Cell Cultivation. Blackwell, Oxford.

[50] Schwyn, B. and Neilands, J.B. (1987) Universal Chemical Assay for the Detection and Determination of Siderophores. Analytical Biochemistry, 160, 47-56. http://dx.doi.org/10.1016/0003-2697(87)90612-9

[51] Payne, S.M. (1994) Detection, Isolation, and Characterization of Siderophores. Methods in Enzymology, 235, 329-344. http://dx.doi.org/10.1016/0076-6879(94)35151-1

[52] Legendre, P., Oksanen, J. and ter Braak, C.J.F. (2011) Testing the Significance of Canonical Axes in Redundancy Analysis. Methods in Ecology and Evolution, 2, 269-277. http://dx.doi.org/10.1111/j.2041-210X.2010.00078.X

[53] Clarke, K. (1993) Non-Parametric Multivariate Analyses of Changes in Community Structure. Australian Journal of Ecology, 18, 117-143. http://dx.doi.org/10.1111/j.1442-9993.1993.tb00438.x

[54] Goldstein, A.H., Braverman, K. and Osorio, N. (1999) Evidence for Mutualism between a Plant Growing in a Phosphate-Limited Desert Environment and a Mineral Phosphate Solubilizing (MPS) Rhizobacterium. FEMS Microbiology Ecology, 30, 295-300. http://dx.doi.org/10.1111/j.1574-6941.1999.tb00657.x

[55] Acevedo, E., Galindo-Castaneda, T., Prada, F., Navia, M. and Romero, H.M. (2014) Phosphate-Solubilizing Microorganisms Associated with the Rhizosphere of Oil Palm (Elaeis guineensis Jacq.) in Colombia. Applied Soil Ecology, 80, 26-33. http://dx.doi.org/10.1016/j.apsoil.2014.03.011

[56] Vazquez, P., Holguin, G., Puente, M.E., Lopez-Cortes, A. and Bashan, Y. (2000) Phosphate-Solubilizing Microorganisms Associated with the Rhizosphere of Mangroves in a Semiarid Coastal Lagoon. Biology and Fertility of Soils, 30, 460-468. http://dx.doi.org/10.1007/s003740050024

[57] Uroz, S., Calvaruso, C., Turpault, M.P., Pierrat, J.C., Mustin, C. and Frey-Klett, P. (2007) Effect of the Mycorrhizosphere on the Genotypic and Metabolic Diversity of the Bacterial Communities Involved in Mineral Weathering in a Forest Soil. Applied and Environmental Microbiology, 73, 3019-3027. http://dx.doi.org/10.1128/AEM.00121-07

[58] Calvaruso, C., Turpault, M.P., Leclerc, E. and Frey-Klett, P. (2007) Impact of Ectomycorrhizosphere on the Functional 
Diversity of Soil Bacterial and Fungal Communities from a Forest Stand in Relation to Nutrient Mobilization Processes. Microbial Ecology, 54, 567-577. http://dx.doi.org/10.1007/s00248-007-9260-z

[59] Ibekwe, A.M., Kennedy, A.C., Halvorson, J.J. and Yang, C.H. (2007) Characterization of Developing Microbial Communities in Mount St. Helens Pyroclastic Substrate. Soil Biology and Biochemistry, 39, 2496-2507. http://dx.doi.org/10.1016/j.soilbio.2007.05.010

[60] Carro, L., Leon-Barrios, M., Gonzalez, M., Velazquez, E. and Valverde, A. (2012) Herbaspirillium canariense sp. nov., Herbaspirillium aurantiacum sp. nov. and Herbaspirillium soli sp. nov., Isolated from Volcanic Mountain Soil, and Emended Description of the Genus Herbaspirillium. International Journal of Systematic and Evolutionary Microbiology, 62, 1300-1306. http://dx.doi.org/10.1099/ijs.0.031336-0

[61] Gomez-Alvarez, V., King, G.M. and Nusslein, K. (2007) Comparative Bacterial Diversity in Recent Hawaiian Volcanic Deposits of Different Ages. FEMS Microbiology Ecology, 60, 60-73. http://dx.doi.org/10.1111/j.1574-6941.2006.00253.X

[62] Huang, J., Sheng, X.F., Xi, J., He, L.Y., Huang, Z., Wang, Q., et al. (2014) Depth-Related Changes in Community Structure of Culturable Mineral Weathering Bacteria and in Weathering Patterns Caused by Them along Two Contrasting Soil Profiles. Applied and Environmental Microbiology, 80, 1542-1550. http://dx.doi.org/10.1128/AEM.04211-13

[63] Hameeda, B., Reddy, Y.H., Rupela, O.P., Kumar, G.N. and Reddy, G. (2006) Effect of Carbon Substrates on Rock Phosphate Solubilization by Bacteria from Composts and Macrofauna. Current Microbiology, 53, 298-302. http://dx.doi.org/10.1007/s00284-006-0004-y

[64] Kim, Y.H., Bae, B. and Choung, Y.K. (2005) Optimization of Biological Phosphorus Removal from Contaminated Sediments with Phosphate-Solubilizing Microorganisms. Journal of Bioscience and Bioengineering, 99, 23-29. http://dx.doi.org/10.1263/jbb.99.23

[65] Kalinowski, B.E., Liermann, L.J., Brantley, S.L., Barnes, A. and Pantano, C.G. (2000) X-Ray Photoelectron Evidence for Bacteria-Enhanced Dissolution of Hornblende. Geochimica et Cosmochimica Acta, 64, 1331-1343. http://dx.doi.org/10.1016/S0016-7037(99)00371-3

[66] Abdulla, H. (2009) Bioweathering and Biotransformation of Granitic Rock Minerals by Actinomycetes. Microbial Ecology, 58, 753-761. http://dx.doi.org/10.1007/s00248-009-9549-1

[67] Buss, H.L., Luttge, A. and Brantley, S.L. (2007) Etch Pits and Leached Layers on Iron-Silicate Surfaces during Siderophore-Promoted Dissolution. Chemical Geology, 240, 326-342. http://dx.doi.org/10.1016/j.chemgeo.2007.03.003

[68] Hersman, L., Lloyd, T. and Sposito, G. (1995) Siderophore-Promoted Dissolution of Hematite. Geochimica et Cosmochimica Acta, 59, 3327-3330. http://dx.doi.org/10.1016/0016-7037(95)00221-K

[69] Kraemer, S.M. (2004) Iron Oxide Dissolution and Solubility in the Presence of Siderophores. Aquatic Sciences, 66, 3-18. http://dx.doi.org/10.1007/s00027-003-0690-5

[70] Furrer, G. and Stumm, W. (1986) The Coordination Chemistry of Weathering: I. Dissolution Kinetics of $\delta$ - $\mathrm{Al}_{2} \mathrm{O}_{3}$ and BeO. Geochimica et Cosmochimica Acta, 50, 1847-1860. http://dx.doi.org/10.1016/0016-7037(86)90243-7

[71] Liermann, L.J., Kalinowski, B.E., Brantley, S.L. and Ferry, J.G. (2000) Role of Bacterial Siderophores in Dissolution of Hornblende. Geochimica et Cosmochimica Acta, 64, 587-602. http://dx.doi.org/10.1016/S0016-7037(99)00288-4

[72] Drever, J.I. and Stillings, L.L. (1997) The Role of Organic Acids in Mineral Weathering. Colloids and Surfaces A: Physicochemical and Engineering Aspects, 120, 167-181. http://dx.doi.org/10.1016/S0927-7757(96)03720-X

[73] Welch, S.A., Taunton, A.E. and Banfield, J.F. (2002) Effect of Microorganisms and Microbial Metabolites on Apatite Dissolution. Geomicrobiology Journal, 19, 343-367. http://dx.doi.org/10.1080/01490450290098414

[74] Welch, S.A. and Ullman, W.J. (1996) Feldspar Dissolution in Acidic and Organic Solutions: Compositional and pH Dependence of Dissolution Rate. Geochimica et Cosmochimica Acta, 60, 2939-2948. http://dx.doi.org/10.1016/0016-7037(96)00134-2

[75] Welch, S.A. and Ullman, W.J. (1993) The Effect of Organic Acids on Plagioclase Dissolution Rates and Stoichiometry. Geochimica et Cosmochimica Acta, 57, 2725-2736. http://dx.doi.org/10.1016/0016-7037(93)90386-B 


\section{Supplementary Data}

Table S1. Primers used for Ion Torrent analysis.

\begin{tabular}{|c|c|c|c|c|}
\hline Name & Ion Torrent Linker Primer & Golay Barcode & Spacer & $\underline{16 S \text { rRNA Primer }}$ \\
\hline
\end{tabular}

A341F_BACT_A_21 5'-CCATCTCATCCCTGCGTGTCTCCGACTCAG-3' 5'-GATCTGCGATCC-3 GT 5'-CCTACGGGAGGCAGCAG-3' A341F_BACT_A_22 5'-CCATCTCATCCCTGCGTGTCTCCGACTCAG-3' 5'-CAGCTCATCAGC-3 GT 5'-CCTACGGGAGGCAGCAG-3' A341F_BACT_A_23 5'-CCATCTCATCCCTGCGTGTCTCCGACTCAG-3' 5'-CAAACAACAGCT-3 GT 5'-CCTACGGGAGGCAGCAG-3' A341F_BACT_A_24 5'-CCATCTCATCCCTGCGTGTCTCCGACTCAG-3' 5'-GCAACACCATCC-3 GT 5'-CCTACGGGAGGCAGCAG-3' A341F_BACT_A_25 5'-CCATCTCATCCCTGCGTGTCTCCGACTCAG-3' 5'-GCGATATATCGC-3 GT 5'-CCTACGGGAGGCAGCAG-3' A341F_BACT_A_26 5'-CCATCTCATCCCTGCGTGTCTCCGACTCAG-3' 5'-CGAGCAATCCTA-3 GT 5'-CCTACGGGAGGCAGCAG-3' A341F_BACT_A_27 5'-CCATCTCATCCCTGCGTGTCTCCGACTCAG-3' 5'-AGTCGTGCACAT-3 GT 5'-CCTACGGGAGGCAGCAG-3' A341F_BACT_A_28 5'-CCATCTCATCCCTGCGTGTCTCCGACTCAG-3' 5'-GTATCTGCGCGT-3 GT 5'-CCTACGGGAGGCAGCAG-3' A341F_BACT_A_29 5'-CCATCTCATCCCTGCGTGTCTCCGACTCAG-3' 5'-CGAGGGAAAGTC-3 GT 5'-CCTACGGGAGGCAGCAG-3' A341F_BACT_A_30 5'-CCATCTCATCCCTGCGTGTCTCCGACTCAG-3' 5'-CAAATTCGGGAT-3 GT 5'-CCTACGGGAGGCAGCAG-3' A341F_BACT_A_31 5'-CCATCTCATCCCTGCGTGTCTCCGACTCAG-3' 5'-AGATTGACCAAC-3 GT 5'-CCTACGGGAGGCAGCAG-3' A341F_BACT_A_32 5'-CCATCTCATCCCTGCGTGTCTCCGACTCAG-3' 5'-AGTTACGAGCTA-3 GT 5'-CCTACGGGAGGCAGCAG-3' A341F_BACT_A_33 5'-CCATCTCATCCCTGCGTGTCTCCGACTCAG-3' 5'-GCATATGCACTG-3 GT 5'-CCTACGGGAGGCAGCAG-3' A341F_BACT_A_34 5'-CCATCTCATCCCTGCGTGTCTCCGACTCAG-3' 5'-CAACTCCCGTGA-3 GT 5'-CCTACGGGAGGCAGCAG-3' A341F_BACT_A_35 5'-CCATCTCATCCCTGCGTGTCTCCGACTCAG-3' 5'-TTGCGTTAGCAG-3 GT 5'-CCTACGGGAGGCAGCAG-3' A341F_BACT_A_36 5'-CCATCTCATCCCTGCGTGTCTCCGACTCAG-3' 5'-TACGAGCCCTAA-3 GT 5'-CCTACGGGAGGCAGCAG-3' A341F_BACT_A_37 5'-CCATCTCATCCCTGCGTGTCTCCGACTCAG-3' 5'-CACTACGCTAGA-3 GT 5'-CCTACGGGAGGCAGCAG-3' A341F_BACT_A_38 5'-CCATCTCATCCCTGCGTGTCTCCGACTCAG-3' 5'-TGCAGTCCTCGA-3 GT 5'-CCTACGGGAGGCAGCAG-3' Reverse Primer

518R_BACT_P1 5'-CCTCTCTATGGGCAGTCGGTGAT-3' $\quad$ Not applicable $\quad$ CC 5'-CGACAGCCATGCANCACCT Table S2. 16S rRNA primers used to create contiguous sequences for isolate identification.

\begin{tabular}{ccc}
\hline$\underline{\text { Name }}$ & $\underline{16 S \text { rRNA Primer }}$ & 5'-AGAGTTTGATCMTGGCTCAG-3' \\
\hline $\mathbf{2 7 f}$ & 5'-AAGGAGGTGATCCAGCC-3’ \\
COM1 & 5'-CAGCAGCCGCGGTAATAC-3' \\
COM2 & 5'-CCGTCAATTCCTTTGAGTTT-3' \\
\hline
\end{tabular}

